\title{
AN EXAMINATION OF CUSTOMER SATISFACTION AND LOYALTY WITH LOW INVOLVEMENT PRODUCTS AMONG THOSE WITH DECREASED INCOME
}

\author{
Melanie Jelen, New York Institute of Technology, New York, New York, U.S.A. \\ Eleanor Schwartz, New York Institute of Technology, New York, New York, U.S.A. \\ John T. LaPerla, New York Institute of Technology, New York, New York, U.S.A. \\ Cristina Seaman, New York Institute of Technology, New York, New York, U.S.A. \\ Jennifer Kalla, Independent Scholar, Massillon, Ohio, U.S.A. \\ Stacey Baez, New York Institute of Technology, New York, New York, U.S.A. \\ Ute Broedje, New York Institute of Technology, New York, New York, U.S.A. \\ Joshua E. Bienstock, New York Institute of Technology, New York, New York, U.S.A.
}

\author{
dx.doi.org/10.18374/JIBE-20-3.5
}

\begin{abstract}
Literature thoroughly examines the relationships among customer satisfaction, brand loyalty and trust over time. The concept of how marketers can influence customer relationship triggers including price and distribution has also been extensively explored. Customer loyalty, as evidenced by repeat purchases, has been examined in low involvement products, which do not require substantial out of pocket investment. Few studies have examined how dramatic decreases in income influence customer loyalty and satisfaction with low risk, low involvement products. The Social Security Administration in 2019 reported that 9 out of 10 people over 65 receive social security benefits. Over 63 million people, or more than one in six U.S. residents received social security benefits in June 2019. The number of people and the percentage of Americans on limited incomes (social security, social security disability, and/or limited pension amounting to less than income while working) is forecast to increase over the next decade. "Only 12\% of Americans aged 65+ received $90 \%$ or more of their income from Social Security" (Biggs, 2020). There is a gap in the literature which fails to differentiate key factors in decision making and how and if brand loyalty is obtained as income falls for low involvement products. The purpose of this research is to explore whether this reduction of income at (often at age 65 or over) will force differences in brand choice and loyalty. A qualitative study is suggested to understand the differences in customer loyalty in low involvement purchases with a reduced disposable income. Both small and large businesses should benefit by understanding this growing population and the factors that impact satisfaction and loyalty for low risk, low involvement products.
\end{abstract}

Keywords: Consumer Satisfaction, Low Involvement Products, Decision-Making, Brand Loyalty, Decreased Income 